\title{
Why farmers hesitate to join agricultural marketing co-operative societies? Evidence from Indian farmers
}

\author{
Arif Abad, Rais Ahmad and Mohd Abdul Muqeet Maaz
}

See end of the paper for authors' affiliations

Correspondence to :

Mohd Abdul Muqeet

Maaz

Department of Agricultural Economics and Business

Management, Aligarh

Muslim University, Aligarh

(U.P.) India

Email:mamaaz@myamu. ac.in

Paper History:

Received : 17.03.2020;

Revised : 22.07.2020;

Accepted : 24.08 .2020
ABSTRACT : The biggest problem for Indian farmers, which is the root cause of every other problem, is middlemen. Middlemen pay very less amount to farmers for their produce and sell it to customers for a high price. Agricultural marketing cooperative societies, which allow a group of farmers to join together and perform all the activities concerned with moving the produce from the producers to the consumers, are the ultimate tool to uplift farmers. Indian farmers hesitate to join Agricultural marketing cooperative societies despite they prefer to be exploited by the middlemen. This research work is therefore aims to find out the roots for this kind of thinking so that the policy makers/government can know exactly what is needed in order to make agricultural marketing cooperatives popular and successful among farmers, so that the conditions of farmers can be improved. In this research work with the help of multistage sampling technique Bidaraka village, from Iglas tehsil of Aligarh district, Uttar Pradesh has been selected and the data has been collected from 311 farmers in that village. This sample size was determined using appropriate formula. Furthermore, with the help of focused interview technique this study identify six variables which influence farmer's decision to join/form agricultural marketing cooperative societies and with the help of multi linear regression model the study analysed these variables in order to find out the extent to which these identified variables are the predictors of the farmers' willingness to join /form agricultural marketing cooperatives. Findings indicate that general and procedural knowledge, cooperation and coordination and willingness to try something new are the major factors that influence farmers' willingness to join/form agricultural Marketing cooperatives followed by family influence, benefits in being a member and freedom in being a member.

KEY WORDS : Cooperatives, agricultural marketing, marketing cooperatives, Indian farmers

How To Cite This Paper: Abad, Arif, Ahmad, Rais and Maaz, Mohd Abdul Muqeet (2020). Why farmers hesitate to join agricultural marketing co-operative societies? Evidence from Indian farmers. Internat. Res. J. Agric. Eco. \& Stat., 11 (2) : 237-247, DOI : 10.15740/HAS/IRJAES/11.2/237-247. Copyright@2020:Hind AgriHorticultural Society. 